\title{
勿忘国耻 \\ The Use of Victor-Victim Historical Narratives in Chinese Nationalist DisCOURSE
}

\author{
Raquel Leslie ${ }^{\mathrm{I}}$
}

\section{INTRODUCTION}

Collective memory and the political use of history serve very important functions both within Chinese society and in China's interactions with other foreign powers. Internally, historical memory plays an integral role in the formation of group membership and identity. Key historical events that a social group highlights define what it means to belong to that group, who the group's enemies may be, and how the group behaves in conflict situations. Externally, national history also provides a common thread that ties together generations across time, including those that have not taken part in certain traumatic events themselves, in order to raise nationalist sentiment.

Since the twentieth century, the Chinese Communist Party (CCP) has tactfully utilized historical memory as a tool to both maintain its legitimacy at home and mobilize the population against its imperialist foes. The invocation of nationalism for political purposes has a long history within China, with the Nationalists utilizing it as a tool to mobilize the masses before the establishment of the CCP. The so-called "Century of Humiliation", referring to the period in which China suffered major invasions at the hands of imperialist powers like Great Britain and Japan, generated a discourse of national humiliation that continues to shape Chinese identity politics and provides the "master narrative" of modern

\footnotetext{
1 Raquel Leslie is a junior at Harvard College studying Government and East Asian Studies with a language citation in Mandarin Chinese. Her research interests include Sino-American relations, immigration, and international law. At Harvard, Raquel is the President of Harvard Model Congress and a tutor for Harvard employees preparing for their US citizenship exam.
} 
Chinese history. ${ }^{2}$ However, there is significant variation in the ways in which the CCP has utilized historical memory throughout the twentieth century. Mao Zedong, for example, grounded the legitimacy of the CCP in its triumph over imperialism in the 1940s and the closure that this victory brought to the Century of Humiliation. The historical narrative that he promoted in the 1950s to $1970 \mathrm{~s}$ centered around China's decline and suffering in modern history as caused mainly by internal corruption among China's own feudal or capitalist rulers, prompting him to rally the masses through bottom-up, grassroots mobilization. Following the 1989 Tiananmen Square massacre, however, the Party faced a devastating legitimacy crisis due to a weakened faith in Communism among the people. In order to prevent the collapse of the regime, Chinese officials identified patriotic education as the solution, employing a more top-down approach by targeting the younger generation with narratives about the suffering and humiliation of the imperialist era in Chinese history. Moving away from Communist and Maoist narratives, national patriotism became the C.C.P.'s ideological tool of choice.

This paper seeks to evaluate the effectiveness of the C.C.P.'s attempts to influence the politics of identity through historical memory, particularly by using patriotic education to redirect the public's energies and attention in a direction that proves beneficial for the prosperity and legitimacy of the party-state. How does nationalism ebb and flow throughout modern Chinese history as a result of the C.C.P.'s manipulation of historical memory? How do the state's motives at a given point in history affect the way it chooses to shape national historical memory? Is the C.C.P. replicating the same methods, and how effective are they? Or have these strategies changed - if so, why? These findings will shed light on the role that historical issues will continue to play in the future landscape of China's foreign relations. My analysis is anchored in the rhetoric of national humiliation generated by the party in regards to the Century of Humiliation. Specifically, I will examine the CCP's patriotic education campaign, manifested in official history textbooks and gaokao exams, as a means to assess the content of the messages promoted by the C.C.P. over time, as well as the success of these ideological indoctrination efforts.

My analysis is two-pronged: first, I seek to compare Maoist era propaganda

\footnotetext{
${ }^{2}$ William Callahan, "History, Identity, and Security: Producing and Consuming Nationalism in China," Critical Asian Studies 38, no. 2 (2006):187.
} 
surrounding national humiliation with the post-1990s patriotic education campaign - both aimed at shoring up regime legitimacy by controlling collective memory - to determine how and why rhetorical strategies employed internally by the CCP changed over time. Externally, I will then contrast the CCP's efforts to shape historical memory and nationalistic sentiment by focusing on specific historical events in the national humiliation discourse, namely the Korean and Vietnam Wars and the Nanjing Massacre, in order to reveal how external, foreign relations motives may determine the different patriotic education strategies that the state uses to shape historical memory. While most scholars researching this field exclusively focus on the role of historical memory in Sino-Japanese foreign relations, I seek to take a more nuanced approach by introducing a comparison using the United States as a counter case in order to illustrate how differential foreign relations can affect historical discourse. The shift between "victor" and "victim" narratives in the portrayal of key historical events helps to understand the CCP's motives behind manipulating historical memory. Rather than relying heavily on sensitive historical grievances as a method of constructing nationalism, the "victor" rhetoric that characterizes China's attitude towards its relations with the US effectively glorifies triumphs in order to mask China's insecurities about US hegemony and reassure itself that it can compete as a global power. I suggest that the victimization narrative prevalent in discourse about Japan is ultimately more dangerous because of its capacity to mobilize negative nationalist sentiment, posing a serious threat to the future of the Sino-Japanese relationship. China's overreliance on the victimization narrative not only delegitimizes its claims as a rising power capable of competing with the US, but it also obstructs the path towards improved relations with Japan. A re-construction of Chinese nationalism that breaks free of the victor-victim dichotomy is therefore necessary to resolve the historical tensions that constrain Chinese foreign policy.

\section{LiTERATURE REVIEW}

\section{Historical Memory and National Identity}

Historical memory both acts as a frame that influences a group's perception of events as well as a motivating factor in times of conflict. Historical memory influences a group's interpretation and understanding of the outside world, often leading actors to "endow a group with certain motives and to interpret the world 
through frames defined by those motives". ${ }^{3}$ Additionally, the socially shared images of the past produced through historical memory and transmitted intergenerationally can foster cohesion and a sense of nationalism within a given group that can be called upon in times of conflict. Zheng Wang points out that leaders often try to evoke memories of past traumas to justify hostility towards out-groups, reshaping national memory in times of identity crisis to reinforce a sense of community. Beyond this, political leaders at times even manipulate memories to portray a certain story or encourage a specific way of thinking, thereby promoting versions of events that meet their political needs. For example, a history of victimization reinforced by the state "can help build a group's self-esteem as the group members begin to see themselves as the progeny of a long line of survivors". 4 The CCP uses China's Century of Humiliation, a reinforcement and perpetuation of the history of victimization narrative, as a political tool used to direct the people's criticism away from domestic corruption and towards foreign enemies.

\section{The Century of Humiliation}

In traditional Chinese thought, the Chinese believed that they lived in the central kingdom of tianxia - a culturally defined community comprised of civilizations rather than nation-states - in which Chinese civilization was considered to be universal and superior. Unlike the Western international system - one that emphasizes military and economic strength, competition, and territorial expansion -the tianxia system focused more on soft power such as culture, morality, and harmony. ${ }^{5}$ This system was based on a common historical heritage and shared beliefs rather than nationalism and the modern concept of the nation-state.

It was the war defeats and unequal treaties China suffered during the Century of Humiliation that finally "awakened" Chinese consciousness of nation-statehood. In this sense, Chinese nationalism can be understood as a result of Western imperialism, in the historical context of the "100 years of

\footnotetext{
3 Zheng Wang, Never Forget National Humilation : Historical Memory in Chinese Politics and Foreign Relations (New York: Columbia University Press, 2012), 24.

4 Ibid., 27.

5 Ibid., 44.
} 
national humiliation". ${ }^{6}$ Many foreign powers took advantage of China's weakness during this period by forcing the nation to sign a series of devastating agreements following military defeats, thereby allowing countries like Russia and Japan to secure Chinese territory and carve out their respective spheres of influence. By forcing China to pay large amounts of reparations, open up ports, and cede lands, these foreign powers severely strangled China's development. Moreover, foreign imperialist aggression dramatically transformed the very fabric of Chinese society, one that had once been based upon community and family harmony. With China having been forced to open up to globalization and Western capitalism, Chinese rural life subsequently declined, migrants headed to cities, and the organization of community life began to crumble as China descended into warlordism following the fall of the Qing.

The major foreign invasions that China faced during the Century of Humiliation include the First Opium War, the Second Opium War, the SinoJapanese War, the invasion of the allied forces of eight countries, the Japanese invasion of Manchuria, and the Anti-Japanese War. According to the official Chinese history narrative, the Opium War in 1840 was the starting point from which China began to "degenerate from an independent country into a semicolonial country," at a time when the British Navy forced China to open its doors to foreign invading traders and Western capitalism. ${ }^{7}$ The Chinese government began to utilize symbolism to remind the people of atrocities committed by foreign powers during the Second Opium War, in which French and British forces joined together against the Qing dynasty and destroyed the Yuanming Yuan royal palace outside of Beijing. After 1949, the Chinese government decided to leave the ruins "as is" in order to remind future generations about Chinese suffering under the influence of imperialism and foreign aggression. Wang highlights that the site is "an icon of national humiliation that is a testament to both the Chinese civilization and foreign barbarism...the ruins have become a physical reminder of what the Chinese historical memory remembers as Western hostility and the 'rape of China"”. ${ }^{8}$

\footnotetext{
${ }^{6}$ Peter Hays Gries, "Chapter 5: Narratives to Live By: The Century of Humiliation and Chinese National Identity Today” (Lanham: Rowman \& Littlefield, 2007), 112.

7 Zheng Wang, Never Forget National Humilation : Historical Memory in Chinese Politics and Foreign Relations (New York: Columbia University Press, 2012), 50.

8 Ibid., 53
} 
Perhaps the greatest humiliation suffered by China during this period was its defeat by Japan, namely the first Sino-Japanese War from 1894-1895. This defeat is especially consequential because it shifted the Sino-Japanese relationship from one of equal footing to Japanese superiority. Forcing many Chinese to reconsider their nation's place in the world, the military defeat exposed the idea that the tianxia system was no longer viable, and that China was now a weak state in danger of collapse. In 1915, the Japanese government put forth its contentious "Twenty-One Demands" to Yuan Shikai's warlord government, demanding extensive economic and commercial rights throughout Chinese territory. Yuan Shikai's acceptance of a modified version of the demands on May 9th outraged the Chinese people and laid the foundations for the second Sino-Japanese War. May 9th was commemorated as an official holiday in China called "National Humiliation Day," with the phrase "Never Forget National Humiliation" coined in Chinese newspapers and social discourse. The TwentyOne Demands therefore became a primary driver of China's first nationalist movement and the search for a new national identity.

The Chinese continued to suffer defeat at the hands of the Japanese, culminating in Japan's capture of Nanjing and the ensuing Nanjing Massacre or "Rape of Nanjing" in 1937. It was not until the United States dropped atomic bombs in Hiroshima and Nagasaki that the Japanese finally surrendered and the Century of Humiliation was supposedly drawn to a close. Official sources also declare that the Communist victory in 1949 marked the end of the Century, given that "the civil war between the Communists and Nationalists was over, foreign influence had been driven from the mainland, and socialism had defeated capitalism". ${ }^{9}$ Peter Hays Gries asserts that Chinese resistance to foreign invasions was not only in defense of their territory, but also to preserve Chinese culture and tradition. Before 1840, the Chinese held a Sinocentric view of Chinese civilization as universal and superior, yet "with each new humiliation, the Chinese lost a bit of their national myth of greatness". ${ }^{10}$ The international system that Western powers forced upon China during the Century of Humiliation fundamentally decentered Chinese views of the world, challenging their perceived universality and superiority of Chinese civilization.

\footnotetext{
9 Peter Hays Gries, "Chapter 5: Narratives to Live By: The Century of Humiliation and Chinese National Identity Today” (Lanham: Rowman \& Littlefield, 2007), 119.

10 Ibid., 117.
} 


\section{Shaping Chinese Nationalism}

Chinese national identity is to a significant extent a product of evolving and contested narratives about China's national past. Shunji Cui conceptualizes the beginning of nationalism in China as a response to the expansion of European influence into East Asia in the 19th century. While culturalism rather than nationalism permeated traditional thought in imperial China, the shift from culturalism to nationalism was accompanied by a strong sense of victimization and humiliation, as symbolized by China's defeat in the Opium War with Britain in 1840-1842. Thus from the start, Chinese nationalism was "strongly associated with a reactive sentiment against imperial expansionism". ${ }^{11}$ When the Chinese borrowed the concept of nationalism from the West, it was to defend China from foreign invasion and to gain independence; instead of being closely associated with ideas of democracy and human rights, nationalism gained a more negative and reactive sense in China. ${ }^{12}$ Friedman (1994) describes this type of nationalism as "anti-imperialist nationalism", while Xiao (1996) refers to it as the "reactivedefensive type" because it arose in response to specific issues and has little to do with abstract ideas or ideologies. ${ }^{13}$

Taking a different approach, Peter Hays Gries presents two common views on the impact of the Century of Humiliation on Chinese nationalism, namely pastism and presentism. Pastism asserts that the past determines the present; for instance, Chinese anger at its early victimization at the hands of Western imperialists may predetermine Chinese revisionism in the 21st century. Presentism offers the opposite perspective, positing that historians and nationalists writing in the present determine the past. Paul Cohen illustrates this point, arguing that Chinese historians "draw on [the past] to serve the political, ideological, rhetorical, and/or emotional needs of the present" ${ }^{14}$ For example, the People's Daily sought to combat Western sanctions in reaction to the post-Tiananmen massacre and garner popular nationalist support by commemorating the 90th anniversary of the

\footnotetext{
${ }^{11}$ Shunji Cui, "Problems of Nationalism and Historical Memory in China's Relations with Japan," Journal of Historical Sociology 25, no. 2 (2012): 204.

${ }^{12}$ Ibid., 205.

${ }^{13}$ Ibid., 205.

14 Paul Cohen, "Remembering and Forgetting National Humiliation in Twentieth-Century China," Twentieth-Century China 27, no. 2 (2002): 2.
} 
Boxer Rebellion, publishing numerous articles describing the brutality of foreign soldiers that marched on Beijing in $1990 .{ }^{15}$ Synthesizing these two approaches, Gries argues that the Century of Humiliation is "neither an objective past that works insidiously on the present (pastism) nor a mere invention of present-day nationalist entrepreneurs (presentism). Past and present, instead, exist in an interactive relationship...mutually constituted through constant dialogue about their relationship to one another". ${ }^{16}$ William Callahan expands on this thought, arguing that national humiliation plays an integral role in the construction of citizenship and national identity in China. The Century of Humiliation provided the motivation and momentum needed to spur a national consciousness-raising or "awakening" movement in China, in which historical events of national humiliation such as the first Sino-Japanese War and the Twenty-One Demands became symbols of China's identity building and the rise of nationalism.

\section{Historical Memory in Sino-Japanese Relations}

Many scholars have written extensively on the critical role of historical memory in Sino-Japanese relations, particularly China's long-standing posture of antagonism towards Japan. Stories of the war atrocities committed by the Japanese against China during the Century of Humiliation continue to haunt the relationship more than sixty years after the end of World War II, with the younger generation learning about events such as the Anti-Japanese War from their grandparents, history classes, museums and historical sites, and propaganda materials. Wang argues that this constant emphasis on remembrance has left many "sensitive historical symbols between the two countries, and these symbols can be 'reactivated' deliberately or unintentionally and can cause major tensions or even conflicts between the two countries," as seen in the massive anti-Japanese protests that broke out in April 2005. ${ }^{17}$

Some intellectuals like Ma Licheng, a well-known editorial writer for

\footnotetext{
15 Peter Hays Gries, "Chapter 5: Narratives to Live By: The Century of Humiliation and Chinese National Identity Today” (Lanham: Rowman \& Littlefield, 2007), 114.

16 Ibid., 115.

17 Zheng Wang, "National Humiliation, History Education, and the Politics of Historical Memory: Patriotic Education Campaign in China," International Studies Quarterly 52, no. 4 (2008): 204.
} 
the People's Daily, have publicly criticized what is seen by some as the excessive nationalism that has characterized attitudes towards Japan, arguing that "China should cease to dwell so much on past injuries and, instead, concentrate on its future partnership with Japan". ${ }^{18}$ Nevertheless, Sino-Japanese relations have continued to deteriorate, and have entered a period often described as "economically hot but politically cold". ${ }^{19}$ On one hand, official relations between China and Japan have improved over the past three decades. The two countries celebrated the 30th anniversary of the normalization of China-Japan relations in September 2002, and the 2nd anniversary of their 1978 Treaty of Peace and Friendship in August 2003. From an economic viewpoint, trade between the two countries reached a record high of $\$ 167.8$ billion in 2004; China became Japan's largest trading partner when imports from China exceeded those from the United States in 2002, while Japan became one of the biggest investors in China, second only to the US. ${ }^{20}$ However, Sino-Japanese relations in the political and security spheres have remained quite tense. For example, Japan publicly identified China as a military threat for the first time in its 2004 defense guidelines, while Chinese Premier Wen Jiabao signaled China's intention to oppose Japan's bid to become a permanent member of the UN Security Council in 2005. That same year, serious anti-Japanese riots broke out in numerous Chinese cities, leading many analysts to believe that Sino-Japanese relations had reached an all-time low since the normalization of $1972 .{ }^{21}$ Chinese and Japanese attitudes towards each other also took a turn for the worse: a Chinese Academy of Social Science (CASS) survey in the fall of 2002 indicated that "only 5.9 percent of Chinese respondents believed that the Chinese and Japanese people are 'very close' or 'close' to each other, whereas 43.3 percent felt that the two people are 'not very close' or 'not close at all'". ${ }^{22}$ Furthermore, opinion polls conducted in both Japan and China in 2002 indicated that a majority of Chinese and Japanese citizens felt that the relations between their nations were not good.

Such deterioration of the Sino-Japanese relationship can be largely

\footnotetext{
18 Shunji Cui, "Problems of Nationalism and Historical Memory in China’s Relations with Japan," Journal of Historical Sociology 25, no. 2 (2012): 200.

19 Ibid., 201.

20 Jin Qiu, “The Politics of History and Historical Memory in China-Japan Relations," Journal of Chinese Political Science 11, no. 1 (2006): 26.

${ }^{21}$ Shunji Cui, "Problems of Nationalism and Historical Memory in China's Relations with Japan," Journal of Historical Sociology 25, no. 2 (2012): 206.

${ }_{22}$ Jin Qiu, "The Politics of History and Historical Memory in China-Japan Relations," Journal of

Chinese Political Science 11, no. 1 (2006): 27.
} 
attributed to issues related to history and its role in the rise of nationalistic sentiment. According to Cui, "the processes of reconstruction and representation of historical memory have played a major part in the shaping of identities and forming the nature of nationalism in both countries". ${ }^{23}$ The way in which the CCP in particular has constructed and represented collective memory has played a decisive role in China's strategic approach to Japan.

However, the focus of much scholarly work on the political use of historical memory in China typically surrounds the Sino-Japanese relationship in isolation. In this paper, I seek to complicate this matter by juxtaposing the role of historical memory in Sino-Japanese relations with that in Sino-US relations, in order to compare the CCP's rationale for constructing historical narratives for differing political aims. This comparison serves to reveal a greater nuance in the CCP's invocation of nationalism than solely the "victim narrative" prevalent in the Sino-Japanese relationship. By analyzing China's patriotic education campaign and the use of textbooks and gaokao exams as vehicles for exporting national historical narratives, I seek to determine the underlying motives and subsequent consequences of the CCP's shifts between promoting "victor" and "victim" narratives. While China experienced an internally-focused temporal shift from the use of "victor" narratives in Maoist era propaganda to "victim" narratives in the patriotic education campaign launched in the mid-1990s, my use of Japan and the US as comparison cases will reveal that the victor-victim distinction plays a critical role in Chinese foreign relations as well.

\section{Analysis I}

Shifting Historical Narratives Amidst a Legitimacy Crisis

The political usage of the humiliation narrative can be traced back to the founding movement of the PRC. Callahan asserts that national humiliation was part of the construction of citizenship and national identity in the Republic of China, with the phrase "never forget national humiliation" (wuwang guochi) having been popularized in newspapers since $1915 .{ }^{24}$ Pre-Mao republican era

\footnotetext{
23 Shunji Cui, "Problems of Nationalism and Historical Memory in China's Relations with Japan," Journal of Historical Sociology 25, no. 2 (2012): 203.

${ }_{24}$ Zheng Wang, Never Forget National Humilation : Historical Memory in Chinese Politics and Foreign Relations (New York: Columbia University Press, 2012), 76.
} 
writings on the Century of Humiliation focused on the concept of victimization, drawing upon images of China as a raped woman in reference to the invasions it suffered at the hands of foreign imperialist powers. However, Gries notes that the "Rape of China" theme faded after the Communist victory in 1949. In fact, Gries points out that during Mao's time, China's national history and the national humiliation narrative were not employed by the CCP as a major ideological tool or source of legitimacy for the party. For example, the memory of the anti-Japanese War had virtually disappeared from public space in China, and records of the National Library of China indicate that there were no books on the subject of "national humiliation" published in China between 1947 and 1990. Kirk Denton also asserts that the historiography of the Nanjing Massacre was consciously suppressed during the Maoist period. ${ }^{25}$

Instead, it was the official communist ideology that was crucial to the institutionalization of the CCP's legitimacy. Gries argues that "theories of historical materialism, class struggle, and scientific socialism provided a comprehensive conceptual framework of moral justification for the new partystate," with Mao tactfully contextualizing Marxism in terms of China's traditional ideal of a Confucian society based on harmony and unity. ${ }^{26}$ Gries outlines several reasons for the CCP putting aside national humiliation narratives during this period of time. Firstly, the CCP "made class distinction rather than ethnicity the foundation of political identity," using class struggle theory to explain the Chinese revolution, foreign imperialism, and Chinese civil wars. Rather than placing the blame on foreign invasions, China's decline and suffering in modern history were said to be primarily caused by internal corruption and the incompetence of the feudal and capitalist rulers in the Qing dynasty. According to Gries, the concept of nationalism would have also contradicted Mao's idea of an "international" communist revolution. Furthermore, "victory" was a key word in the CCP's claims to legitimacy, a narrative intended to mobilize popular support; the CCP's propaganda machine taught that it was under Mao's brilliant leadership that the party ultimately emerged victorious and gained national independence. A rhetoric of national humiliation clearly would have contradicted these victor narratives. Mao-era propaganda also highlighted the heroism of the anti-feudal, anti-

25 Peter Hays Gries, "Chapter 5: Narratives to Live By: The Century of Humiliation and Chinese National Identity Today” (Lanham: Rowman \& Littlefield, 2007), 115.

26 Ibid., 116. 
imperialist masses in "throwing off their chains and repelling foreign invaders" ${ }^{27}$ From the founding of the CCP to the establishment of the PRC in 1949, the CCP claimed legitimacy on the grounds of "changing China's weak country status and reviving its central position on the world stage," with the party setting aside the concept of nationalism and the memory of humiliation.

Following Mao's death in 1976, however, the CCP faced a legitimacy crisis, in which the official communist ideology began to lose credibility. The "Three Beliefs Crises" emerged after the Cultural Revolution: a crisis of faith in socialism, a crisis of belief in Marxism, and a crisis of trust in the party. ${ }^{28}$

\section{The Patriotic Education Campaign}

In reaction to the bankruptcy of Marxist and Maoist ideologies, there was "a felt, if unstated, need on the part of the Chinese government to come up with a new legitimating ideology to burnish the rapidly dimming luster of the original Marxist-Leninist-Maoist vision”. ${ }^{29}$ It was in this context that in the early 1990s, the Chinese government realized that history education on national humiliation could be an effective device for the regime to re-legitimize its rule and inspire nationalism. A China Youth Daily article published at the time asserted that "in order to prevent the possible disintegration of Chinese society, China must base itself firmly on nationalism which would provide the basis for its national cohesion (ningjuli) and political integration". ${ }^{30}$ Ideological education, therefore, became the primary strategy that the CCP would use to handle its legitimacy crisis, particularly because patriotic education in particular "stressed the role of the communist state as the bearer of China's historic struggle for national independence and therefore reinforced CCP authority". ${ }^{31}$ The CCP began to move away from communist narratives, reviving national humiliation

\footnotetext{
27 Ibid., 116.

28 Zheng Wang, Never Forget National Humilation : Historical Memory in Chinese Politics and Foreign Relations (New York: Columbia University Press, 2012), 78.

29 Paul Cohen, "Remembering and Forgetting National Humiliation in Twentieth-Century China," Twentieth-Century China 27, no. 2 (2002): 4.

${ }^{30}$ China Youth Daily, "Sulian jubian zhihou Zhongguo de xianshi yingdui yu zhanlue xuanze," China Youth Daily, 9 September 1991.

31 Zheng Wang, Never Forget National Humilation : Historical Memory in Chinese Politics and Foreign Relations (New York: Columbia University Press, 2012), 97.
} 
discourse and introducing patriotism as the new ideological tool of choice. This allowed the CCP to reassert its claim to legitimacy by stressing the suffering and humiliation that China had experienced at the hands of foreign imperialist powers like Japan, exemplified by events like the Nanjing massacre of 1937.

Officially launched in 1994, the patriotic education campaign was not so much one of reeducation as of redirection. Namely, it was an effort to redirect young people's anger away from the party and domestic issues and back to foreign problems. Paul Cohen highlights the fact that a sizable majority of the Chinese population in the 1990s had been born after 1949, and had therefore never directly experienced the imperialist aggression portrayed in national humiliation discourse. Patriotic education provided the ideal opportunity to reintroduce these individuals "to the imperialist past, to re-experience its bitterness and shame". ${ }^{32}$

Although the campaign began in the early 1990s with the intent of targeting young students in particular, it has gradually evolved into an institutionalized nationwide mobilization. Beyond formal education in the classroom, the Party's 1994 "Outline for Implementing Patriotic Education" also proposed a multimedia campaign of patriotic education activities that set the state's entire propaganda machine in motion, taking place not just in schools, but also in museums, film, television, popular magazines, newspapers, and national holidays. Beijing has "creatively used history education as an instrument for the glorification of the party, the consolidation of the PRC's national identity, and the justification of the political system of one-party rule by the CCP... skillfully utilizing China's humiliating past to arouse its citizens' historical consciousness and to promote social cohesion". ${ }^{33}$ Not only representing a major shift in Beijing's identity politics, the campaign very directly allowed for the party's survival in the post-Cold War and post-Tiananmen eras.

\section{Textbook Reform}

History textbooks in particular play a central role in the construction and reproduction of national narratives, often used by the state as "ideological tools

\footnotetext{
32 Paul Cohen, "Remembering and Forgetting National Humiliation in Twentieth-Century China," Twentieth-Century China 27, no. 2 (2002): 2.

33 Zheng Wang, Never Forget National Humilation : Historical Memory in Chinese Politics and Foreign Relations (New York: Columbia University Press, 2012), 116.
} 
to promote a certain belief system and legitimize an established political/social order" ${ }^{34}$ Textbooks have the capacity to convey a uniform and even official version of what the leadership wants the youth to believe, therefore textbooks serve as major components in the construction and reproduction of national narratives.

A critical component of the patriotic education campaign involved the revision of history curriculum. The Official People's Education Press published new history textbooks, including a new characterization of China's modern history, for both middle and high schools in 1992 - one that emphasized the "bullying and humiliation" of Chinese people under foreign powers. According to Wang, the new textbooks repeated the CCP's typical interpretation of Chinese history: "if not for the CCP's successful revolution and sacrifice, China would still be a weak and divided country". ${ }^{35}$ However, rather than emphasizing a class struggle narrative as the Chinese ruling regime had done in the past, the textbooks approved after 1992 focused on the struggle with outside forces. In other words, the patriotic education campaign featured a major narrative change from "victor" to "victim" narratives, in which "the 'traditional' historical narrative that had previously focused on tales of Maoist and socialist triumphs was significantly reduced" and it its place was "a new historiography that emphasized China's century of suffering and humiliation due to incessant foreign invasions and oppression". ${ }^{36}$ Wang asserts that the traditional "victor" narratives had not been useful in cultivating the young generation's antagonistic attitude towards China's own enemies like Japan, at the same time making them less appreciative of the Communist revolution and the CCP's role in changing China's fate and ending national humiliation. Because most schools in China are run by the state, they provided the ideal social institution through which the CCP could transmit national narratives about the past. ${ }^{37}$ Modern and contemporary Chinese history has become a required core course in high school since 1992, with the Ministry

\footnotetext{
${ }^{34}$ Ibid., 103.

35 Ibid., 79.

36 Shan Windscript, "A Modern History of Forgetting: The Rewriting of Social and Historical Memory in Contemporary China, 1966-present," Quarterly Journal of Chinese Studies 1, no. 4 (2013): 64-65.

37 Zheng Wang, Never Forget National Humilation : Historical Memory in Chinese Politics and Foreign Relations (New York: Columbia University Press, 2012), 97.
} 
of Education exercising direct authority over educational content and teaching methods. Wang provides the official narrative of modern Chinese history presented at the beginning of the teaching guidelines for the new high school history course:

Chinese modern history is a history of humiliation in which China gradually degenerated into a semi-colonial and semi-feudal society; at the same time, it is also a history that Chinese people strived for national independence and social progress and persisted in their struggle of anti-imperialism and antifeudalism. It is also a history of the success of the New-Democratic Revolution under the leadership of the Chinese Communist Party.

This type of "education on national humiliation" has become one of the most important subjects in the national education system, an initiative that continues to bolster the legitimacy of the CCP through the manipulation of collective memory.

From "Victor" to "Victim" in History Textbooks

In order to test the validity of these claims about revisions in history curriculum as a result of the patriotic education campaign, I identified passages in Chinese textbooks and gaokao exams as primary sources to present evidence of this narrative change from the "victor" narrative of the Maoist era to the "victim" narrative of the post-1990s period. Firstly, examples of the emphasis on class struggle that Mao promoted prior to 1976 can be found in the politics section of the 1963 gaokao exam. One excerpt conceptualizes imperialism within a class struggle framework, asserting that "As long as imperialism still exists in other countries, there exists an international class struggle. The imperialists not only carry out political subversion and military aggression against the socialist countries, but also infiltrate and erode the socialist countries ideologically and culturally". ${ }^{38}$ The original Chinese text is below:

(2)在国外: 只要帝国主义还存在, 就存在着国际范围内的阶级斗争. 帝 国主义不但要对社会主义国家进行政治颠覆和军事侵略, 而且还会从思想 上、文化上对社会主义国家进行渗透和侵蚀, 阴谋实现社会主义内部的“和 平演变”。

381963 Colleges and universities enrollment unified national examination (gaokao), Political section. 
The portrayal of the Anti-Japanese War in particular has dramatically transformed over time. Prior to patriotic education, the CCP depicted the Anti-Japanese War in Marxist terms, describing Japanese workers and peasants as fellow victims of militant imperialists. Significant emphasis was also placed on internal and class conflict between the CCP and KMT; in the early 1980s, history textbooks "provided detailed descriptions about KMT corruption and impotence along with its nonresistance policy" and also "purported that the anti-Japanese War was fought solely by Communist troops". ${ }^{39}$ However, the narrative of the AntiJapanese War was revised in the mid-1990s, with the emphasis now placed on the international and ethnic conflict between China and Japan. For example, one college entrance exam prep book dives into extensive detail on the signing of the Treaty of Shimonoseki and the seizure of occupied land following the AntiJapanese War, blaming the colonialization of Chinese society on imperialists' division of China into "spheres of influence". ${ }^{40}$

Likewise, the depiction of modern Chinese history in historical texts transformed from a story of class struggle to one of national humiliation and the Chinese struggle for liberation from foreign powers. In accordance with the national humiliation narrative, the 2007 Guangdong volume of the history gaokao exam posits that scholars advocate the interpretation of Chinese modern history as a "process of the Chinese people's resistance to imperialism and feudalism" . ${ }^{41}$ One Grade 8 Chinese history textbook published in 2006 presents a similar victimization narrative, writing that the founding of the People's Republic of China opened up a new era of Chinese history, whereby China "ended more than a century the history of humiliation in which the country was enslaved but ultimately became an independent country...From then on, the Chinese people have 'stood up' as the masters of the country" and "expanded the forces of peace, democracy and socialism in the world and inspired the struggle of oppressed people and nations for liberation" ${ }^{\prime 2}$ :

\footnotetext{
39 Zheng Wang, Never Forget National Humilation : Historical Memory in Chinese Politics and Foreign Relations (New York: Columbia University Press, 2012), 212.

40 Tianmin Feng and Shaowen Wang, "Li Shi ed. Xin Bian Quan Guo Cheng Ren Gao Kao Fu Dao Cong Shu," (Beijing: Guang Ming Ri Bao Chu Ban She, 1999): 104.

412007 Colleges and universities enrollment unified national examination (gaokao), Guangdong volume.

42 Shi Jie Li Shi (Beijing: Ren Min Jiao Yu Chu Ban She, 2008): 7.
} 
中华人民共和国的成立开辟了中国历史新乣元。从此，中国结束了一百多 年来被侵略被奴役的屈軍历史, 真正成为独立向主的国家; 中国人民从此站起 米了, 成为国家的主人。

新中国的成立, 壮大了虫界和平、民主和社会主义的力量, 鼓舞了世界被 压迫民族和被压迫人民争取解放的斗争。

Furthermore, numerous textbooks published after the mid-1990s use a rhetoric of victimization to describe the Opium War and the havoc it wreaked upon the development of Chinese society. In describing the series of unequal treaties that the Qing government was forced to sign after the Opium War, a college entrance exam textbook emphasizes the importance of understanding the humiliation narrative: "Only by grasping the main content of these unequal treaties can we analyze the harm they exerted on the Chinese nation. This is the only way to understand how China has gradually reduced itself to semi-colonial and semi-feudal society. The treaties undermined China's independence, sovereignty, and territorial integrity" ${ }^{33}$ :

\section{辟商埠及其它特权等四方面。只有掌握了主要内容, 才 能分析它的危害和对中华民族所带来的巨大灾难。也只有这 样才能明了中国是如何一步步沦为半殖民地半封建社会的。 《中英南京条约》及其附件的签订和鸦片战争均给中国造成 极大的危害和影响，但其具体内容又有所不同，前者破坏了 中国的独立和领土完整，增加了中国人民的负担，破坏了中 国的关税自主权和司法权，扩大了资本主义国家的侵略权}

The excerpt goes on to highlight how capitalist countries dumped their commodities into China in vast quantities, undermining the self-sufficient natural economy of China and causing the dissolution of the feudal economy.

However, a critical component of the victimization narrative is an emphasis on how the Chinese ultimately persevered in the struggle for liberation. The same textbook also includes a section that describes an anti-tobacco campaign led by Lin Zexu during the Opium War, in which he defended the interests of the nation against attempts by British colonialists to plunder China's wealth. The textbook

43 Tianmin Feng and Shaowen Wang, "Li Shi ed. Xin Bian Quan Guo Cheng Ren Gao Kao Fu Dao Cong Shu," (Beijing: Guang Ming Ri Bao Chu Ban She, 1999): 101. 
portrays this as a "victory of the Chinese people against smoking" that "cracked down upon foreign invaders and showed the strong will of the Chinese people to resist foreign aggressors". ${ }^{44}$ The concept of the Chinese having "shouldered the dual revolutionary task of opposing aggression and anti-feudalism" is a common theme amid the renewed "victim" narrative.

\section{Analysis II}

\section{Differential Use of Historical Narratives in Foreign Relations}

Although this victor-victim narrative shift is clearly prevalent in the period between Mao-era propaganda and after the launch of the patriotic education campaign, this distinction is not just temporal - the historical narrative employed by the CCP also varies in response to foreign relations. This is best exemplified by the case studies conducted by Peter Hays Gries on the endurance of the Mao-era victor narrative in Chinese writings about the Korean War, compared to the reemergence of the victim narrative in recent anti-Japanese discourse. He points out that beyond simple variation in time accounting for the use of either "victor" or "victim" narratives in internal Chinese discourse, external foreign policy is an equally decisive factor in the CCP's manipulation of historical memory. Gries presents an interesting argument for the reasoning behind the CCP's differentiated use of historical narratives in its relations with the United States and Japan in particular, asserting that "insecurity about growing American power may explain why writings about the U.S. have clung to the victor narrative, while increasing confidence about a rapidly developing China's ability to take on Japan may explain why popular nationalists in China have embraced a victim narrative about China's past conflicts with Japan" ${ }^{45}$

\section{Evoking Glorious "Victories" in Sino-U.S. Relations}

To begin with the idea of heroism in Sino-U.S. relations, the Korean War marks the end of the Century of Humiliation for many Chinese people as well as

\footnotetext{
${ }_{44}$ Tianmin Feng and Shaowen Wang, "Li Shi ed. Xin Bian Quan Guo Cheng Ren Gao Kao Fu Dao Cong Shu," (Beijing: Guang Ming Ri Bao Chu Ban She, 1999): 105.

45 Peter Hays Gries, "Chapter 5: Narratives to Live By: The Century of Humiliation and Chinese National Identity Today” (Lanham: Rowman \& Littlefield, 2007), 123.
} 
the birth of New China. While official sources frequently declare that the period ended in 1945 with Chinese participation in the Allied victory over Japan, many Japanese and Westerners instead assign victory to the U.S. when the atomic bombs dropped on Hiroshima and Nagasaki. ${ }^{46}$ The Communist victory in 1949 was also not completely satisfying in the fact that Taiwan and Hong Kong had yet to be returned to Chinese control. However, victory over the U.S. in the Korean War could be construed as something special; the perception of victory in this battle, therefore, plays a central role in the self-confidence of many Chinese nationalists. Gries points out that "several of the Chinese narratives about Korea were written during the Taiwan Straits Crisis (1996), when many Chinese acquired the selfesteem to take on and defeat the United States". ${ }^{47}$ Drawing upon proud narratives of past "victories" over the United States, like in Korea or Vietnam, can therefore help create the confidence necessary for possible future Sino-U.S. conflicts.

Gries asserts that Mao's need to disparage the U.S. as a "paper tiger" revealed an anxiety about American power that still persists today. In the 1950s, Mao referred to the American military as the "world's number one military power" yet claimed that the Chinese people defeated it by "relying on their own strength," completely dismissing North Korean contributions to the Korean War and asserting that China won on its own. ${ }^{48}$ As tensions with the United States rise today, Chinese nationalists continue to evoke glorious "victories" over the U.S. in the past and draw upon this pride in order to meet present-day challenges in foreign relations. In the case of the Taiwan Strait Crisis of 1996, the Chinese leadership responded to the U.S. sending an aircraft carrier to Taiwan following People's Liberation Army (P.L.A.) missile exercises directed at the island by declaring that "China has dealt with the US on more than one or two occasions. What was the outcome? The United States was defeated on every occasion". ${ }^{49}$ Additionally, popular nationalist Xi Yongjun and Ma Zaizhun called upon similar imagery of victory in their 1996 Surpassing the USA: "On the Taiwan question, Americans have forgotten the enormous losses they bitterly suffered on the Korean battlefield and in ...Vietnam...China is strengthening, and the myth of American invincibility

\footnotetext{
46 Ibid., 119.

47 Ibid., 118.

48 Ibid., 119.

49 Peter Hays Gries, "Chapter 5: Narratives to Live By: The Century of Humiliation and Chinese National Identity Today” (Lanham: Rowman \& Littlefield, 2007), 120.
} 
has already been shattered". ${ }^{50}$

\section{Portrayal of The Korean and Vietnam Wars in Textbooks}

As with the temporal shift in victor-victim narratives from the Mao era to the patriotic education campaign, I again used textbooks and gaokao exams as primary sources to identify evidence of the depiction of Chinese "victories" over the United States in both the Korean and Vietnam Wars. Firstly, there are elements of fear over the rise of US hegemony in depictions of the Korean War. In a high school history book on "Twentieth Century War and Peace" published in 2007, the text warns against the United States' efforts to expand its interests in East Asia and "further promote its own hegemon policy around the world and step up the siege of the socialist camp". ${ }^{51}$ However, the textbook then employs a rhetoric of victory and courage in its description of China answering the Democratic People's Republic of Korea (D.P.R.K.)'s call for military support. In order to resist U.S. imperialism, "safeguard national security," and aid the D.P.R.K. in its fight of "socialist resistance," the C.C.P. Central Committee Political Bureau and the Central Government "made careful consideration to decide to form a Chinese People's Volunteer Army on October 19, 1950, under the leadership of Commander Peng Dehuai". ${ }^{52}$ One passage of a Grade 8 Chinese history textbook encourages students to reflect on the heroism of the Volunteer Army, writing “The People's Volunteers Army fought shoulder to shoulder with the North Korean army and civilians and emerged countless epic war heroes in bloody battles with their enemies. Do you want to know their heroic deeds?". ${ }^{3}$ A few pages later, the textbook credits the victory of the Korean War to these soldiers: "In the War to Resist the U.S. and Aid Korea, the Chinese People's Volunteers Army carried forward a high degree of patriotism and revolutionary heroism. Because of their heroic fighting with North Korean soldiers and civilians, in July 1953 the United States was forced to sign the Armistice Agreement. The people of China won the war against aggression. The Chinese People's

\footnotetext{
50 Ibid., 120.

5120 Shi Ji De Zhan Zheng Yu He Ping (Beijing: Ren Min Jiao Yu Chu Ban She, 2007): 106.

${ }^{52}$ Ibid., 107.

53 Zhong Guo Li Shi (Beijing: Ren Min Jiao Yu Chu Ban She, 2008): 7.
} 
Volunteers returned triumphantly". ${ }^{44}$ In order to establish a sense of superiority and victory over the adversary, the high school history textbook on "Twentieth Century War and Peace" published in 2007 declares that "the Korean War... broke the myth of the invincible U.S. military...the imperialists' attempt to stifle the riches of the Asian countries through wars had failed utterly". ${ }^{55}$ Finally, the teacher's guide for the Grade 8 Chinese history textbook provides a teaching objective on the Korean War lesson, instructing teachers to present the following storyline: "The just struggle against aggression not only safeguarded the security and independence of China and the D.P.R.K., but also encouraged the liberation struggle of the oppressed nations in the world, severely attacked the U.S. policy of aggression and expansion, and greatly enhanced the international status and prestige of New China"56:

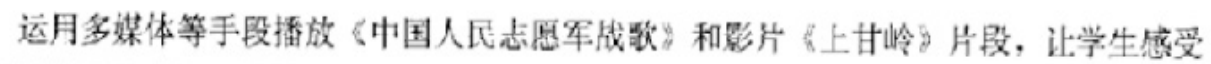
志泉军战上的豪边、热情、坚强的决心和英勇放强的抗争皘神, 深刻体会志意军战上所表 现出来的爱国主义、国际主义和革命英雄主义精神, 他们仆魄为 “最可爱的人”。抗美援 朝是一场伟大的反侵略的正义斗争, 晓保上了中胡两国的安全和独立, 也鼓舞了全世界被 压迫民旅的解放斗争, 沉重打击了美国的侵格扩张政筑, 极入的提高了新中国的国际地位 和国际咸望。

Likewise, the portrayal of the Vietnam War in gaokao exams and history textbooks follows the same pattern of evoking glorious "victories" over the United States. In the politics section of the 1965 gaokao exam, the answer key suggests that students present two core ideas in response to the question of why the "victory of the Vietnamese people in the struggle against the United States is significant for

54 Zhong Guo Li Shi (Beijing: Ren Min Jiao Yu Chu Ban She, 2008): 13-14.

5520 Shi Ji De Zhan Zheng Yu He Ping (Beijing: Ren Min Jiao Yu Chu Ban She, 2007): 108.

56 Zhong Guo Li Shi, Ba Nian Ji (Beijing: Ren Min Jiao Yu Chu Ban She, 2006): 15. 
national salvation and victory over U.S. imperialism": "1. The war of aggression in Vietnam by the U.S. imperialists is unjust, reactionary, barbarous, and extremely unpopular; 2. The struggle of the Vietnamese people for resisting the United States and saving the nation is not only for the purpose of safeguarding its own sovereignty but also for defending socialism. It has won the sympathy and support of the people of the world, especially the support of 650 million Chinese people, for the revolutionary interests of freeing the oppressed nations" ${ }^{57}$ Furthermore, the high school history textbook on "Twentieth Century War and Peace" invites students to question the motives of the United States in launching yet another war in Asia after the Korean War, asking "Why, then, do Americans go all the way to Asia to fight? What is the impact of the failure of the United States in Vietnam on this as well as the international situation?". ${ }^{58}$ While many U.S. citizens perceive the Korean and Vietnam Wars as senseless tragedies, many Chinese see them as unqualified victories over a potentially threatening foe.

\section{Victimization in Sino-Japanese Relations}

The Century of Humiliation remains a contested narrative revolving around two competing yet coexisting storylines: the "victor" narrative continues to be more prevalent in nationalist accounts of Sino-American relations, while the "victim" narrative is more commonly employed in writings about Japan. What explains this difference? Gries asserts that it is more than just the fact that the Chinese have suffered more at the hands of the Japanese than at the hands of the United States; past wars with Japan and the U.S. actually hold very different meanings for Chinese nationalists today. Events such as the "Rape of Nanjing" and other WWI atrocities must be understood "in the context of a centuries-old Chinese view of the Japanese as subordinate within a Sino-centric world order" ${ }^{59}$ Hence, the notion of Chinese victimization at the hands of "little brother" Japan is tied to strong feelings of injustice. While the Chinese emphasize heroism and past "victories" over the U.S - whether in Korea or Vietnam - to build confidence

\footnotetext{
571965 Colleges and universities enrollment unified national examination (gaokao), Political section.

5820 Shi Ji De Zhan Zheng Yu He Ping (Beijing: Ren Min Jiao Yu Chu Ban She, 2007): 110.

59 Peter Hays Gries, "Chapter 5: Narratives to Live By: The Century of Humiliation and

Chinese National Identity Today” (Lanham: Rowman \& Littlefield, 2007), 123.
} 
about possible future conflicts with the US in the face of an expanding American hegemony, it may be that Chinese citizens "no longer fear Japan as they fear the U.S." and can "engage in a new anti-Japanese 'victim-speak' that allows them to express long-repressed anger at past injustices". ${ }^{60}$

I assert that the victimization narrative prevalent in the Sino-Japanese relationship is more dangerous because of its capacity to mobilize nationalist sentiment in a way that threatens the possibility of reconciliation in the future. The controversy surrounding history education and the revision of history textbooks is not just an issue in China but in East Asia more broadly; Japan is guilty of the same manipulation of historical truth. ${ }^{61}$ In fact, the Japanese Education Ministry approved a new junior high school textbook titled Atarashii rekishi kyokasho (New history textbook) written by the Japanese Society for History Textbook Reform (J.S.H.T.R.) in April 2005, a publication that sparked immediate outrage in Asian countries like China. According to critics, the textbook presented "a distorted and self-serving account of Japan's colonial and wartime activities" that sought to minimize Japan's culpability for its wartime actions. ${ }^{62}$ Four days after the textbook was approved, an estimated 10,000 to 20,000 Chinese demonstrators marched to the Japanese Embassy in Beijing, throwing stones at the facility. The next day, 20,000 protesters marched in two cities in the southern Guangdong province, and protesters attacked a Japanese department store in Shenzhen. After this two-week period passed, Wang writes that anti-Japanese protests had broken out in over ten Chinese cities, with demonstrators chanting slogans like "Japan Must Apologize to China," "Never Forget National Humiliation," and "Boycott Japanese Goods". ${ }^{63}$ The 2005 protests were the largest anti-Japanese demonstrations in China since the two countries normalized diplomatic relations in 1972, and the largest protests against any country since 1999 when the U.S. bombed the Chinese embassy in Belgrade.

In Japan, many people connect China's anti-Japanese sentiments with Chinese history education, including Japanese foreign minister Nobutaka Machimura who accused Beijing of using the patriotic education campaign as a

60 Peter Hays Gries, "Chapter 5: Narratives to Live By: The Century of Humiliation and Chinese National Identity Today” (Lanham: Rowman \& Littlefield, 2007), 124.

61 Zheng Wang, Never Forget National Humilation : Historical Memory in Chinese Politics and Foreign Relations (New York: Columbia University Press, 2012), 205.

62 Ibid., 206.

63 Ibid., 207. 
means of indoctrinating China's students with a biased view of the past. In reality, however, both countries utilize a mix of both "victor" and "victim" narratives in their history textbooks to account for their past conflicts. While Chinese textbooks provide detailed accounts of the wartime atrocities committed by the Japanese, Wang points out that "such content is downplayed in most Japanese textbooks... instead, the Japanese versions tend to associate the war with the atomic bombings of Hiroshima and Nagasaki and the air raids on Tokyo" ${ }^{64}$ According to Saburo Ienaga, Japanese textbooks have taught generations of children that war is glorious since the 1920s, revealing the government's reluctance to portray wartime events in a "detailed and critical manner" ${ }^{65}$ When two countries describe the same historical events in different ways in their respective history textbooks, these discrepancies can lead to serious misunderstandings in their bilateral relations. Sensitivity to history is particularly prevalent in countries with a long history of conflict like Japan and China, and leads to disputes over the accuracy of the portrayal of historical events. These create a "source of new conflicts between old enemies".66

\section{The "Rape of Nanjing": Debating Historical Truths in Textbooks}

One of the most contentious historical episodes between China and Japan is the Nanjing Massacre. For Chinese people, the "Rape of Nanjing" is a national trauma that continues to haunt Sino-Japanese relations today. The official Chinese estimate is that 300,000 people were executed by the Japanese military after they conquered the city in December 1937; this is also the figure that Chinese students have been taught in their history textbooks. The official middle school history textbook provides very descriptive accounts of how the Japanese forces executed people on a massive scale and disposed of their bodies. However, Wang points out that there is no mention of the Nanjing Massacre in the 2005 version of the history textbook published by the JSHTR, with only one passage referring to the event:

${ }^{64}$ Zheng Wang, Never Forget National Humilation : Historical Memory in Chinese Politics and Foreign Relations (New York: Columbia University Press, 2012), 207.

65 Ibid., 207.

66 Ibid., 208. 
In August 1937, two Japanese soldiers [and] one officer were shot to death in Shanghai. After this incident, the hostilities between Japan and China escalated. Japanese military officials thouht Chiang Kai-shek would surrender if they captured Nanking [Nanjing], the Nationalist capital; they occupied that city in December. But Chiang Kai-Shek had moved his capital to the remote city of Chongqing. The conflict continued.

Editors of the textbook added a footnote that makes the only direct reference to the Massacre, albeit at very ambiguous one: "At this time, many Chinese soldiers and civilians were killed or wounded by Japanese troops (the Nanking Incident). Documentary evidence has raised doubts about the actual number of victims claimed by the incident. The debate continues even today" ${ }^{67}$ Further research by Wang indicated that only two of the seven middle school textbooks used in Japan in 2002 gave numbers for the controversial death toll of the Nanjing Massacre, while others used more ambiguous terms such as "many" or "massive" to describe the casualties. Because the revised Japanese textbook casts doubts on China's claim of the number of casualties in Nanjing, Jin Qiu highlights that many Chinese believe that the changes in the textbooks indicate that Japan "lacks a minimal objective attitude on the issue of history" and has not learned lessons from its past". ${ }^{68}$ However, Qiu also points out that the Japanese government continually downplays the issue, explaining that because the textbook in question is only one of several approved textbooks, it does not necessarily represent the official Japanese view on history. In another light, the textbooks revisions can also be viewed as "the government's response to the recent surge of nationalism in the country, especially among young Japanese. The continuing decline of Japan's economy in recent years has begun to shake the confidence that the Japanese have had in their government and country in the postwar era," therefore "glorification of the country's imperial tradition may work as a psychological remedy to the public". ${ }^{69}$

67 Zheng Wang, Never Forget National Humilation : Historical Memory in Chinese Politics and Foreign Relations (New York: Columbia University Press, 2012), 209.

68 Jin Qiu, "The Politics of History and Historical Memory in China-Japan Relations," Journal of Chinese Political Science 11, no. 1 (2006): 27.

${ }^{69}$ Ibid., 28. 


\section{Conclusion}

\section{Policy Implications: Towards a Discourse of Peace?}

Rising nationalist sentiments as a result of the contentious use of victimization narratives pose a serious threat to the future of Sino-Japanese relations. Scholars have voiced similar criticisms of the CCP's manipulation of historical memory through the patriotic education campaign. In January 2006, Yuan Weishi, a professor of philosophy at Zhongshan University in Guangzhou, published an article entitled "Modernization and History Textbooks" in the weekly supplement of the China Youth Daily, in which he accused the government's history text of feeding students "fake pills" and "fostering blind nationalism and close-minded anti-foreign sentiment". ${ }^{70}$ In particular, Yuan cited the accounts of the burning of the Yuanming Yuan and the Boxer Rebellion to argue that the official history textbook published by the People's Education Press provided a one-sided account of historical events. Although party officials quickly responded to the publication of the article by replacing the chief editors of the magazine, the implications of Yuan's point are worth considering. While evoking a sense of nationalism helped the CCP to replace the discredited communist ideology in the 1990s, there remains a danger that rising nationalist sentiment "may cause a serious backlash or even undermine China's attempts to cultivate the image of a responsible power" in accordance with its "peaceful rise" strategy. ${ }^{71}$ While, on one hand, it is in China's best interests to promote social and political stability through sustained economic growth - an objective best achieved through good relations with Japan and the US - this goal is not easily reconciled with antagonistic nationalist discourse based on a clear distinction between "we" against the "other". ${ }^{72}$ Despite Beijing's wishes to improve relations with Japan, its foreign policy remains constrained by history-related factors.

It is the very construction of Chinese nationalism that limits the CCP's flexibility in its foreign relations. China's "overreliance on history to provide national legitimization could challenge the ability of any Chinese government

\footnotetext{
70 Zheng Wang, Never Forget National Humilation : Historical Memory in Chinese Politics and Foreign Relations (New York: Columbia University Press, 2012), 78.

71 Shunji Cui, "Problems of Nationalism and Historical Memory in China's Relations with Japan,” Journal of Historical Sociology 25, no. 2 (2012): 206.

72 Ibid., 206.
} 
to satisfy its own people or to engage easily internationally". ${ }^{73}$ China's repeated deployments of its own historical weaknesses and victim identity are not only incongruent with the reputation it is attempting to build as a rising power catching up to the United States, but actively impede progress in the improvement of its relations in East Asia. Due to the anti-Japanese nature of Chinese nationalism, Cui asserts that Beijing has created a barrier that makes any significant compromise or historical reconciliation in its dealings with Tokyo very difficult to achieve. A reframing of Chinese nationalism - a conceptualization that does not rely so heavily on the victor-victim dichotomy - must serve as the first step that China must take on the path to resolving the historical issues that remain a source of tension in its foreign relations. Unless the CCP accepts the responsibility to guide public opinion towards Japan in a more positive direction, public antagonism rooted in unresolved historical problems, especially among the young generation, will remain a primary obstacle to the development of bilateral relations. Whether Beijing undertakes yet another historical narrative shift from one of victimization to one of peace remains to be seen.

73 Zheng Wang, Never Forget National Humilation : Historical Memory in Chinese Politics and Foreign Relations (New York: Columbia University Press, 2012), 208. 


\section{BIBLIOGRAPHY}

1963 Colleges and universities enrollment unified national examination (gaokao), Political section

1965 Colleges and universities enrollment unified national examination (gaokao), Political section.

2007 Colleges and universities enrollment unified national examination (gaokao), Guangdong volume.

Callahan, William A. "History, Identity, and Security: Producing and Consuming Nationalism in China." Critical Asian Studies 38, no. 2 (2006): 179-208.

China Youth Daily. "Sulian jubian zhihou Zhongguo de xianshi yingdui yu zhanlue xuanze" (Realistic Responses and Strategic Choices for China after the Disintegration of the Soviet Union). China Youth Daily, 9 September 1991.

Cohen, Paul A. "Remembering and Forgetting National Humiliation in Twentieth-Century China." Twentieth-Century China 27, no. 2 (2002): $1-39$.

Cui, Shunji. "Problems of Nationalism and Historical Memory in China's Relations with Japan.” Journal of Historical Sociology 25, no. 2 (2012): 199-222.

Feng, Tianmin., and Wang, Shaowen. Li Shi. First ed. Xin Bian Quan Guo Cheng Ren Gao Kao Fu Dao Cong Shu (New adult college entrance counseling series). Beijing: Guang Ming Ri Bao Chu Ban She (Guangming Daily Press), 1999.

Hays Gries, Peter. "Chapter 5: Narratives to Live By: The Century of Humiliation and Chinese National Identity Today" in Jensen et al. China's Transformations: The Stories beyond the Headlines. Lanham: Rowman \& Littlefield, 2007. 
Ke Cheng Jiao Cai Yan Jiu Suo. Zhongguo Li Shi = Zhongguolishi. Ba Nian Ji. Xia $\mathrm{Ce}$, (Compulsory education curriculum standard experimental textbook). Second ed. Beijing: Ren Min Jiao Yu Chu Ban She, 2006.

Ke Cheng Jiao Cai Yan Jiu Suo. Shi Jie Li Shi = Shijielishi. Jiu Nian Ji. Xia Ce. Second ed. Beijing: Ren Min Jiao Yu Chu Ban She, 2008.

Ke Cheng Jiao Cai Yan Jiu Suo. Zhongguo Li Shi. Ba Nian Ji. Xia Ce, Jiao Shi Jiao Xue Yong Shu (Compulsory education curriculum standard experimental textbook, Teacher guide). Second ed. Beijing: Ren Min Jiao Yu Chu Ban She, 2006.

Qiu, Jin. "The Politics of History and Historical Memory in China-Japan Relations." Journal of Chinese Political Science 11, no. 1 (2006): 25-53.

Ren Min Jiao Yu Chu Ban She, and Ke cheng jiao cai yan jiu suo. Li Shi. Xuan Xiu. 3, 20 Shi Ji De Zhan Zheng Yu He Ping (Twentieth Century War and Peace). Second ed. Beijing: Ren Min Jiao Yu Chu Ban She, 2007.

Wang, Zheng. "National Humiliation, History Education, and the Politics of Historical Memory: Patriotic Education Campaign in China." International Studies Quarterly 52, no. 4 (2008): 783-806.

Wang, Zheng. Never Forget National Humiliation: Historical Memory in Chinese Politics and Foreign Relations. Contemporary Asia in the World. New York: Columbia University Press, 2012: Chapters 1-4.

Windscript, Shan. "A Modern History of Forgetting: The Rewriting of Social and Historical Memory in Contemporary China, 1966-present." Quarterly Journal of Chinese Studies 1, no. 4 (2013): 59-68. 